\title{
Demographic, clinical, and laboratory factors associated with renal parenchymal injury in Iranian children with acute pyelonephritis
}

\author{
Daryoosh Fahimi ${ }^{1}$, Leila Khedmat ${ }^{2}$, Azadeh Afshin ${ }^{3}$, Mohsen Jafari ${ }^{4}$, Zakeyeh Bakouei ${ }^{5}$, Effat Hosseinali Beigi ${ }^{6}$, \\ Mohammad Kajiyazdi ${ }^{7}$, Anahita Izadi ${ }^{4}$ and Sayed Yousef Mojtahedi ${ }^{3^{*}}$ (1)
}

\begin{abstract}
Background: The association between renal parenchyma changes on dimercaptosuccinic acid (DMSA) scans and demographic, clinical, and laboratory markers was assessed in pediatric patients with acute pyelonephritis.

Methods: A retrospective study of 67 Iranian babies and children aged 1-month to 12-year with APN was conducted between 2012 and 2018. The presence of renal parenchymal involvement (RPI) during APN was determined using technetium-99m DMSA during the first 2 weeks of hospitalization. The association of DMSA results with demographic data, clinical features (hospitalization stay, fever temperature and duration), and laboratory parameters such as pathogen type, and hematological factors (ESR, CRP, BUN, $\mathrm{Cr}, \mathrm{Hb}$, and WBC) was evaluated.

Results: $92.5 \%$ of children with an average age of $43.76 \pm 5.2$ months were girls. Twenty-four children (35.8\%) did not have renal parenchymal injury (RPI), while 26 (38.8\%) and 17 (25.4\%) patients showed RPI in one and both kidneys, respectively. There was no significant association between RPI and mean ESR, CRP, BUN, and WBC. However, there were significant associations between RPI and higher mean levels of $\mathrm{Cr}, \mathrm{Hb}$, and BMI.

Conclusions: Low BMl and $\mathrm{Hb}$ levels and increased $\mathrm{Cr}$ levels might be indicative of the presence of RPI in children with APN.
\end{abstract}

Keywords: Acute pyelonephritis, Children, Renal scan, Tc-99m DMSA, Laboratory markers

\section{Background}

Urinary tract infection (UTI) is one of the most common childhood bacterial diseases worldwide [1-3]. It is more prevalent in girls than boys [4]. Upper UTI could cause renal parenchymal injury (RPI) and subsequent progression to formation of renal parenchymal scars. Moreover, UTI increases the level of stress and anxiety among children and their parents $[1,5,6]$. UTI can involve the upper tract especially kidneys (acute pyelonephritis

*Correspondence: Drmojtahedi@tums.ac.ir

${ }^{3}$ Department of Pediatric Nephrology, Bahrami Hospital, Tehran

University of Medical Sciences, Tehran, Iran

Full list of author information is available at the end of the article
$(\mathrm{APN}))$ and/or the lower urinary tract including urethra (urethritis) or the bladder (cystitis) [2-4]. However, it is difficult to discriminate them from each other in babies and young children based on clinical symptoms and laboratory results [7]. Finding the proper methodologies for timely diagnosis and treatment is essential because any delay significantly increases the risk of complications such as hypertension, preeclampsia, growth retardation, and progressive kidney scarring and failure later in life [8-10].

Researchers have been looking for affordable and accessible markers with maximum sensitivity and specificity and the least invasive to predict UTI with RPI. The differentiation between upper and lower UTIs, the tracing 
of abnormalities, and the implementation of appropriate follow-up measures among pediatric patients have been made possible recently [11-13]. Technetium-99m dimercaptosuccinic acid (Tc-99m DMSA) is a standard imaging technique to diagnose RPI $[14,15]$. The technique contributes to the definitive assessment of separate kidney function and total radionuclide uptake. A reduction in the radionuclide uptake can be observed in the damaged locations of kidneys. However, if a DMSA scan is normal during a febrile UTI, no scarring will result from that infection [16]. It could also be used to identify the extent of the RPI in the acute phase and on subsequent follow-up [17].

Factors associated with the risk of RPI in children with APN include gender, age, urinary abnormalities (especially vesicoureteral reflux (VUR)), bacterial virulence, recurrence of infection, and bladder dysfunction [18]. Renal parenchymal damage is significantly associated with an increase in levels of laboratory markers of inflammation such as white blood cells (WBCs), erythrocyte sedimentation rate (ESR), and C-reactive protein (CRP) $[15,19]$. Accordingly, it seems that the comparison of demographic and laboratory markers with Tc-99m DMSA scans can contribute to an understanding of the risk factors that are predictive of the presence of RPI in children with APN and could therefore serve as early prognostic parameters. Therefore, this 10-year retrospective study aimed to explore the relationships between demographic, clinical, and laboratory indicators and renal DMSA scans of Iranian babies and children with febrile UTI.

\section{Methods}

\section{Study design and subjects}

This study was retrospectively conducted based on the data census of all pediatric patients with APN. All the patients were admitted to Bahrami Hospital (Tehran, Iran), affiliated with Tehran University of Medical Sciences (TUMS), between March 2012 and March 2018. A total of 67 children with APN were evaluated. Verbal and written informed consent was obtained from their parents using phone contact and face-to-face interview methods. Each child had a single code number to maintain the confidentiality of participants' data. The research procedure was entirely consistent with the Human Ethics Committee of the TUMS.

\section{Inclusion and exclusion criteria}

All 1-month to 12-year-old patients with APN admitted to Bahrami Hospital were included in the study. The criteria for diagnosis of pyelonephritis included axillary temperatures of over $38.5{ }^{\circ} \mathrm{C}$, poor general condition as indicated by presence of abdominal and flank pains, vomiting, and agitation [20], and positive urine culture (PUC). A PUC was defined as presence of colony count in midstream urine sample more than or equal to $10^{5} \mathrm{CFU} / \mathrm{mL}$ of a single pathogen, or $\geq 10^{4} \mathrm{CFU} / \mathrm{mL}$ in urine sample obtained by catheter method, or $\geq 10^{3}$ Gram-positive bacteria or any number of gram-negative bacteria in urine obtained by suprapubic aspiration (SPA) [21]. Suprapubic aspiration was carried out in babies and children aged 1 month-1.5 years of age, catheterization in 1.5-4 years of age, and clean catch urine collection (Quick-Wee) in 4.5-12 years old [22]. Children with all three criteria were included in the study, while patients with a history of urinary reflux, VUR, urinary tract surgery, urinary tract abnormality, or previous renal scar (presence of photopenic areas with shrinkage and thinning of the renal cortex on DMSA scan), and any preexisting malformations were excluded.

\section{Data collection}

The medical information of the patients was collected from archived electronic files available from March 2012 to March 2018. The keyword "pyelonephritis" was first searched to prepare a list of patients. After ensuring the accuracy of pyelonephritis diagnosis, the necessary information was extracted by referring to the history, disease course, and summary of patients' files. The RPI severity during acute febrile UTI using the Tc-99m DMSA was that determined at the first 2 weeks of hospitalization. If the hospital records contained the necessary information, the patients' clinic records were studied to extract their DMSA scan related-information. If the DMSA scan data was ambiguous or insufficient, the patient's parents and specialists were contacted. This DMSA scan information was divided into three groups: (I) patients with normal kidney scans or without RPI $(n=24)$, (II) patients with RPI in one kidney $(n=26)$, and (III) patients with abnormal scans in both kidneys $(n=17)$. In this study, the association of severity of involvement of each of the left and right kidneys in groups II and III with body mass index (BMI), glomerular filtration rate (GFR), and other laboratory factors (ESR $>20 \mathrm{~mm} / \mathrm{h}, \mathrm{CRP}>10 \mathrm{mg} / \mathrm{L}$, leukocytosis (WBCs $>11 \times 10^{9} / \mathrm{L}$ ), and anemia [hemoglobin $(\mathrm{Hb})<10.5 \mathrm{~g} / \mathrm{dL})]$ was separately determined $[19,22$, 23]. The Kirby-Bauer disk diffusion method was used to assess the antibiotic susceptibility of the bacterial isolates [24].

All the information on eligible patients was imported to pre-prepared questionnaires. The data collected included age, gender, height, weight, BMI, fever degree, duration of fever before and after treatment, duration of hospital stay (HS), and results of urine culture, blood urea nitrogen $(\mathrm{BUN})$, serum creatinine $(\mathrm{SCr}), \mathrm{Hb}, \mathrm{WBCs}$, CRP, ESR, and estimated GFR (eGFR). The kidney 
function level at the time of admission was assessed by determination of the eGFR $\left(\mathrm{mL} / \mathrm{min} / 1.73 \mathrm{~m}^{2}\right)$ using the following equation [25]: $e G F R=\frac{0.413 \times \operatorname{Height}(\mathrm{cm})}{\mathrm{SCr}(\mathrm{mg} / \mathrm{dL})}$

As the level of SCr in children is dependent on their age and gender, this biochemical marker was normalized with the median $\mathrm{SCr}$ value at the corresponding age and gender. The body height of children was measured using a stadiometer with an accuracy of $0.1 \mathrm{~cm}$. An infantometer was used to measure the recumbent length of young children $(<24$ months old). The body weight was measured by wearing light clothes and no shoes or socks using a standard electronic balance with an accuracy of $0.01 \mathrm{~g}$. The BMI was determined by dividing the weight (in $\mathrm{Kg}$ ) divided by the square of height (in $\mathrm{m}$ ).

\section{Data analysis}

The data at a significant level of $\mathrm{p}<0.05$ were analyzed using the SPSS software package version 21.0 (SPSS Inc., Chicago, IL, USA). The descriptive data are represented as frequencies, percentages, and means \pm standard deviations. The significance of differences between means and frequencies was assessed using independent $\mathrm{t}$-test (continuous variables) and Chi-square $\left(\chi^{2}\right.$, categorical variables). Multiple means were compared using analysis of variance (ANOVA). A multiple logistic regression analysis was also carried out to assess the independence of association of demographic, clinical and laboratory factors with DMSA scan changes. Pearson's coefficient was considered to find any significant correlation between tested variables.

\section{Results}

Sixty-seven infants and children, 5 boys $(7.5 \%)$ and 62 girls $(92.5 \%)$ were included in the study. Overall, 43 (64.2\%) had renal parenchymal involvement, RPI, on DMSA scan while 24 (35.8\%) did not. Among those with RPI $(n=43)$, it was unilateral in 26 children $(60.5 \%)$ and bilateral in 17 (39.5). Among those with unilateral RPI $(\mathrm{n}=26)$, the left kidney was involved in in all 5 boys, and in only $28(45.2 \%)$ of the 62 girls $(\mathrm{p}=0.049)$, while right kidney involvement was present in $1 / 5(20.0 \%)$ versus 26/62 (41.9\%; $\mathrm{p}=0.647)$.

The differences in demographic, clinical and laboratory indices between children with versus without RPI, children with involvement of left versus right versus both kidneys, and those with unilateral versus bilateral involvement are set out in Tables 1 and 2. Table 1 features the differences in means plus/minus standard deviations and Table 2 the differences in frequencies and proportions. The only significant differences were in BMI, and serum creatinine and hemoglobin levels (Tables 1 and $2)$. Children with RPI had a significantly lower mean BMI $(p=0.045)$ and higher number with abnormal
BNI $(p=0.038)$, a higher mean serum creatinine level $(\mathrm{p}=0.034)$ and higher number with abnormal levels $(\mathrm{p}=0.042)$, and lower hemoglobin level $(\mathrm{p}=0.048)$ and higher number with anemia (hemoglobin level $<10.5 \mathrm{~g} /$ $\mathrm{dL}[22,23] ; \mathrm{p}=0.035)$. Those with bilateral RPI similarly had a significantly lower mean BMI $(\mathrm{p}=0.039)$ and higher number with abnormal BNI $(\mathrm{p}=0.029)$, a higher mean serum creatinine level $(\mathrm{p}=0.044)$ and higher number with abnormal levels $(p=0.045)$, and lower hemoglobin level $(\mathrm{p}=0.045)$ and higher number with anemia (hemoglobin level < $10.5 \mathrm{~g} / \mathrm{dL}[22,23] ; \mathrm{p}=0.040$ ).

Table 3 shows that the order of effectiveness of predictors associated with the presence of abnormalities on renal scan changes among the children with APN was $\mathrm{Hb}$ (anemia) $>\mathrm{SCr}>\mathrm{BMI}$. The correlation results of these parameters revealed that the strongest association was with BMI and $\mathrm{SCr}$ levels $(\mathrm{p}<0.05 ; \mathrm{r}=0.894)$.

The patients had a PUC with six pathogen types. As expected, Escherichia coli was the most frequent pathogen and was isolated in $89.4 \%$ urine samples. The other bacterial species were Gram-negative bacilli $(\mathrm{n}=2$; $3.03 \%)$, Klebsiella pneumoniae $(\mathrm{n}=2 ; 3.03 \%)$, Acinetobacter $(\mathrm{n}=1 ; 1.51 \%)$, Enterococcus $(\mathrm{n}=1 ; 1.51 \%)$, and Group B Streptococcus $(\mathrm{n}=1 ; 1.51 \%)$. There was no significant association between LKCs and bacterial species. There were three girls with recurrent UTI (4.5\%), and $E$. coli was the isolate from these children. The antibiotic susceptibility of the $E$. coli isolates showed the highest prevalence of resistance to ampicillin $(87.2 \%)$ and cotrimoxazole (83.2\%), while the highest prevalence of sensitivity was to gentamicin (75.1\%) and imipenem (72.9\%).

\section{Discussion}

Our findings showed that both the presence (RPI present versus absent) and pattern (unilateral versus bilateral RPI, and RPI in left versus right kidney) of RPI as diagnosed using DMSA scans had significant associations with only three factors including BMI, SCr, and hemoglobin level.

Obesity is associated with an increased risk of febrile UTI and APN [26-29]. The high BMI in obese children can negatively affect the function of immune cells through the generation of chronic low-grade systemic inflammation, changes in the complex interactions of adipokines, immune cells, and cellular metabolism, as well as epigenetic changes. The dysregulation of immune responses disturbs the normal balance of sympathetic and parasympathetic activity to control voiding and urine storage and leads to UTI or APN [26]. 60-65\% of patients with febrile UTIs may have APN [30]. We however found that children with LKCs and bilateral RPI have lower BMI values than those with normal DMSA scans. Thus, low BMI could be also a significant risk factor for UTI and development of severe infection with RPI in children 


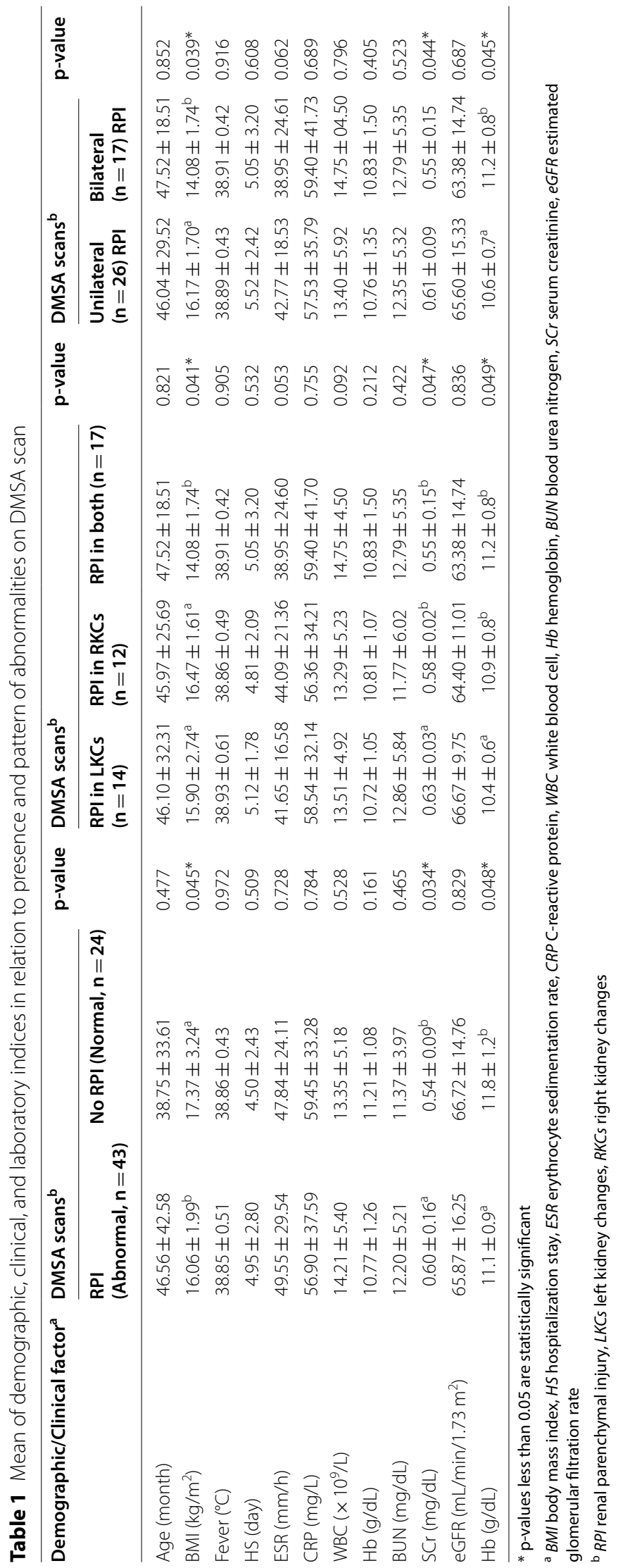




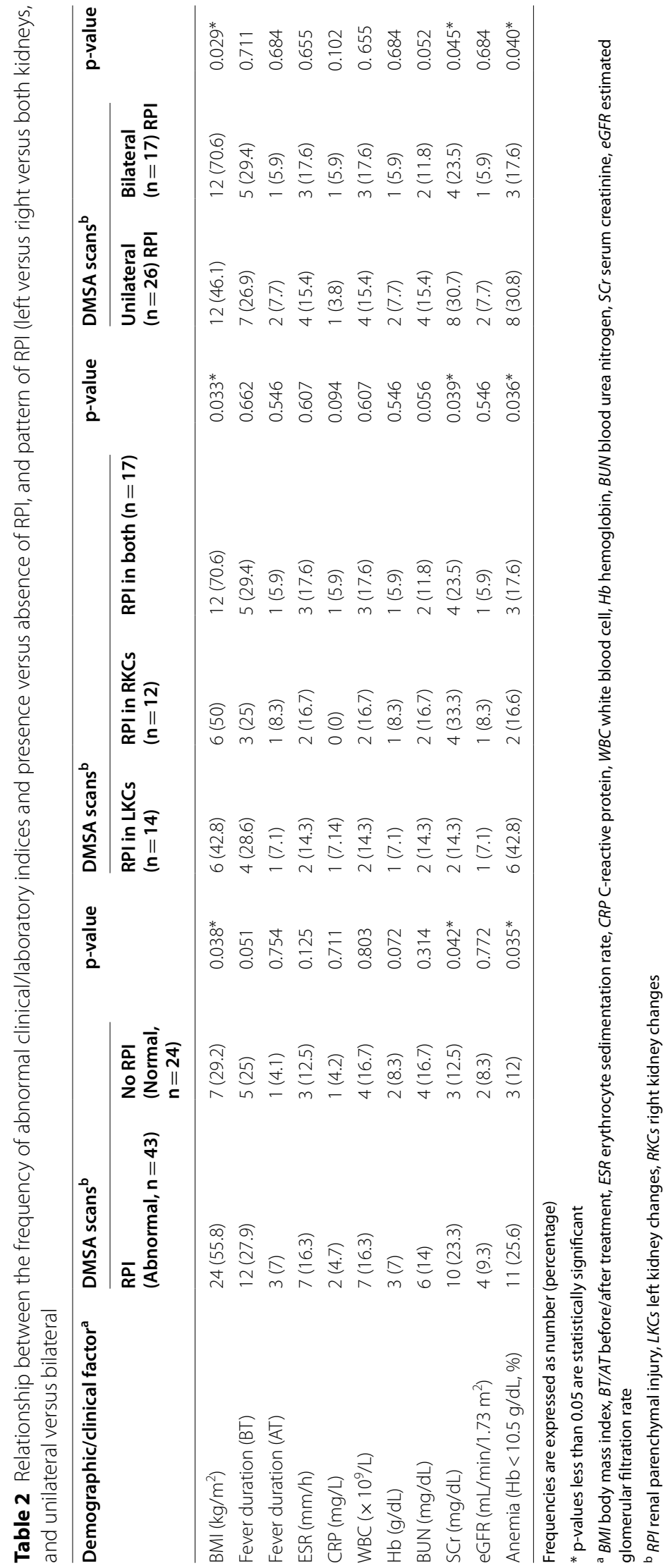


Table 3 Results of multiple logistic regression for the association between demographic/clinical presence of RPI on DMSA scans

\begin{tabular}{lrcll}
\hline Variables & Beta & Odds ratio & $\mathbf{9 5 \%} \mathbf{C l}$ & p-value \\
\hline $\mathrm{BMl}$ & 0.314 & 1.368 & $0.932-1.614$ & 0.0411 \\
$\mathrm{Hb}$ & -0.693 & 0.500 & $0.276-0.805$ & 0.0193 \\
$\mathrm{SCr}$ & 3.689 & 40.004 & $0.598-2579.1$ & 0.0367 \\
\hline
\end{tabular}

Dependent variable: DMSA renal scan changes (positive: 1 , negative: 0 )

in developing countries (such as Iran), probably reflecting malnutrition and poor hygiene standards. The weak immunity among undernourished persons has been attributed to the depleted leucocyte, lymphocyte, and T-cell counts, increased CD4/CD8 ratios, and decreased CD2/CD19 ratios [31, 32]. However, optimal antimicrobial therapy may improve the BMI effect on the gut microbiota [27, 33], and the linkage between changed gut microbiota and human metabolism [34], as well as bone growth and development [35].

There was a significant association between the presence of renal parenchyma changes and increased SCr. Similarly, Ataei et al. [36] reported a significant correlation between renal parenchyma changes and increased SCr, but Amaral et al. [37] did not report any. This discrepancy may be due to the unbalanced alterations in muscle mass and tubular secretion and their effects on the SCr levels [38]. Breinbjerg et al. [39] also found that even non-E. coli infections can lead to an elevated SCr in children after their first ANP. In addition, Megged [40] found that $\mathrm{SCr}$ was the only independent risk factor for bacteremia among children with UTI. This association could be because hypotension from bacteremia decreases blood flow to the kidneys, resulting in increased $\mathrm{SCr}$ levels [41]. The oxidative stress induced by reactive oxygen species during infection along with a reduction in the concentration of antioxidant enzymes (e.g., superoxide dismutase (SOD), catalase (CAT), and glutathione peroxidase (GPx)) may also be an important factor in the pathogenesis of kidney damage and elevation of SCr levels [41-43].

Compared with $\mathrm{SCr}$ and BMI, the presence of anemia was more indicative of the presence and severity of APN. The low Hb levels in children with APN may be due to activation of the renin-angiotensin-aldosterone system, leading to enhanced tubular reabsorption of water and consequent dilutional anemia [44]. In addition, Viana et al. [45] have pointed out that a number of acute bacterial/viral infections can also lead to anemia through mild idiopathic hemolysis, marrow inhibition, and iron deficiency.

In this study, no significant associations were identified between the presence of RPI and the other clinic-laboratory parameters. Ataei et al. [36] did not also report any significant correlations between the presence of abnormalities on Tc-99m DMSA scan and hematological parameters like WBC, ESR, and CRP nor did. Jaksic et al. [30] also report any significant association with gender, age, temperature, ESR, and CRP.

Patients with more severe PI had a longer duration of fever, both before and after the commencement of treatment. This could be because the formation of renal scar is more a reflection of inflammatory tubular damage than bacterial growth in the kidneys. Fever is a result of the local inflammatory response to circulating immune cells and the production of different acute-phase proteins. Therefore, further proliferation and renal scar can be stimulated at higher fever degrees [46]. E. coli was the most common bacterial isolate from children with UTI. This pathogen and other Enterobacteriaceae, because of the biosynthesis of hydrolytic enzymes like extended-spectrum $\beta$-lactamase, have a high ability to acquire resistance against a wide spectrum of antibiotics. Therefore, it is necessary to choose an efficient antimicrobial agent to treat pediatric UTIs [47].

\section{Conclusions}

We conclude that a lower BMI, higher SCr, and anemia are significantly associated with the presence of RPI in children with febrile UTI. Evaluating these demographic and laboratory features might be helpful to identify pediatric patients with APN who require a close follow-up of renal function.

\section{Abbreviations \\ APN: Acute pyelonephritis; BMI: Body mass index; BUN: Blood urea nitrogen; CRP: C-reactive protein; ESR: Erythrocyte sedimentation rate; (e)GFR: (Esti- mated) glomerular filtration rate; Hb: Hemoglobin; HS: Hospitalization stay; (R) PI: (Renal) parenchymal involvement; LKCs: Left kidney changes; PUC: Positive urine culture; RKCs: Right kidney changes; SCr: Serum creatinine; Tc-99m DMSA: Technetium-99m dimercaptosuccinic acid; UTI: Urinary tract infection; VUR: Vesicoureteral reflux; WBCs: White blood cells.}

\section{Acknowledgements}

The authors wish to thank patients and their parents who assisted with conducting this research project.

\section{Authors' contributions}

ZB and DF performed research and analyzed data; SYM, AA, and MJ designed research, interpreted the data, and critically reviewed the manuscript; LK, EHB, $M K$, and Al drafted the work and substantively contributed to scientific editions and discussions. All authors read and approved the final manuscript.

\section{Funding}

The author(s) received no financial support for the research, authorship, and/ or publication of this article.

\section{Availability of data and materials}

The datasets used and/or analyzed during the current study are available from the corresponding author on reasonable request. 


\section{Declarations}

\section{Ethics approval and consent to participate}

The study's protocol with an ethical code of IR.TUMS.MEDICINE.REC.1397.759 was approved by the Ethics Committee of Tehran University of Medical Sciences (Tehran, Iran), and all methods were performed following the relevant guidelines and regulations. The verbal and written informed consent was obtained from all the children and their parents or legal guardian before implementing this study.

\section{Consent for publication}

Not applicable.

\section{Competing interests}

The authors declare that they have no conflict of interests.

\section{Author details}

${ }^{1}$ Children's Hospital Medical Centre, Tehran University of Medical Sciences, Tehran, Iran. ${ }^{2}$ Health Management Research Center, Baqiyatallah University of Medical Sciences, Tehran, Iran. ${ }^{3}$ Department of Pediatric Nephrology, Bahrami Hospital, Tehran University of Medical Sciences, Tehran, Iran. ${ }^{4}$ Department of Pediatric Infection Disease, Tehran University of Medical Sciences, Tehran, Iran. ${ }^{5}$ Faculty of Medicine, Tehran University of Medical Sciences, Tehran, Iran. ${ }^{6}$ Department of Pediatric Intensive Care Unit, Bahrami Children's Hospital, Tehran University of Medical Sciences, Tehran, Iran. ${ }^{7}$ Department of Pediatric Hematology and Oncology, Tehran University of Medical Sciences, Tehran, Iran.

Received: 8 January 2021 Accepted: 15 October 2021

\section{Published online: 24 October 2021}

\section{References}

1. Okarska-Napierała M, Wasilewska A, Kuchar E. Urinary tract infection in children: diagnosis, treatment, imaging - comparison of current guidelines. J Pediatr Urol. 2017;13(6):567-73. https://doi.org/10.1016/j.jpurol. 2017.07.018.

2. Mojtahedi SY, Rahbarimanesh A, Khedmat L, Izadi A. The prevalence of risk factors for the development of bacteraemia in children. Open Access Maced J Med Sci. 2018;6(11):2023-9. https://doi.org/10.3889/oamjms. 2018.418.

3. Rahbarimanesh A, Mojtahedi SY, Sadeghi P, Ghodsi M, Kianfar S, Khedmat L, Siyahkali SJ, Yazdi MK, Izadi A. Antimicrobial stewardship program (ASP): an effective implementing technique for the therapy efficiency of meropenem and vancomycin antibiotics in Iranian pediatric patients. Ann Clin Microbiol Antimicrob. 2019;18(1):6. https://doi.org/10.1186/ s12941-019-0305-1.

4. Yousefichaijan P, Rafiei M, Eghbali A, Sharafkhah M, Taherahmadi H, Naziri $M$, et al. Mean platelet volume: a useful marker in reflux nephropathy. J Pediatr Nephrol. 2014;2(4):137-9. https://doi.org/10.22037/jpn.v2i4.6715.

5. Yousefichaijan P, Dorreh F, Shahsavari S, Pakniyat A. Comparing between results and complications of doing voiding cystourethrogram in the first week following urinary tract infection and in 2-6 weeks after urinary tract infection in children referring to a teaching hospital. J Renal Inj Prev. 2016;5(3):144-7. https://doi.org/10.15171/jrip.2016.30.

6. Mofid V, Izadi A, Mojtahedi SY, Khedmat L. Therapeutic and nutritional effects of synbiotic yogurts in children and adults: a clinical review. Probiotics Antimicrob Proteins. 2020;12:851-9. https://doi.org/10.1007/ s12602-019-09594-x.

7. Balighian E, Burke M. Urinary tract infections in children. Pediatr Rev. 2018:39(1):3-12. https://doi.org/10.1542/pir.2017-0007.

8. Hsu CN, Lu PC, Hou CY, Tain YL. Blood pressure abnormalities associated with gut microbiota-derived short chain fatty acids in children with congenital anomalies of the kidney and urinary tract. J Clin Med. 2019;8(8):1090. https://doi.org/10.3390/jcm8081090.

9. Izadi A, Khedmat L, Tavakolizadeh R, Mojtahedi SY. The intake assessment of diverse dietary patterns on childhood hypertension: alleviating the blood pressure and lipidemic factors with low-sodium seafood rich in omega-3 fatty acids. Lipid Health Dis. 2020;19:65. https://doi.org/10.1186/ s12944-020-01245-3.
10. Izadi A, Khedmat L, Mojtahedi SY. Nutritional and therapeutic perspectives of camel milk and its protein hydrolysates: a review on versatile biofunctional properties. J Funct Food. 2019;60: 103441. https://doi.org/ 10.1016/j.jff.2019.103441.

11. Kostic D, dos Santos Beozzo GP, do Couto SB, Kato AH, Lima L, Palmeira $P$, et al. First-year profile of biomarkers for early detection of renal injury in infants with congenital urinary tract obstruction. Pediatr Nephrol. 2019;34(6):1117-28. https://doi.org/10.1007/s00467-019-4195-4.

12. Kara S, Gökceoğlu AU, Demirel ÖÖ, Koyuncu P. Evaluation of antimicrobial peptides at the diagnosis of urinary tract infection in children. Int J Pept Res Ther. 2020. https://doi.org/10.1007/s10989-020-10083-x.

13. Ammenti A, Alberici I, Brugnara M, Chimenz R, Guarino S, La Manna A, et al. Updated Italian recommendations for the diagnosis, treatment and follow-up of the first febrile urinary tract infection in young children. Acta Paediatr. 2020;109(2):236-47. https://doi.org/10.1111/apa.14988.

14. Guarino S, Capalbo D, Martin N, Campana G, Rambaldi PF, del Giudice EM, et al. In children with urinary tract infection reduced kidney length and vesicoureteric reflux predict abnormal DMSA scan. Pediatr Res. 2020;87(4):779-84. https://doi.org/10.1038/s41390-019-0676-1.

15. Mohkam M. Novel urinary biomarkers for diagnosis of acute pyelonephritis in children. Iran J Kidney Dis. 2020;14(1):1-7.

16. Barati L, Safaeian B, Mehrjerdian M, Vakili MA. Early prediction of renal parenchymal injury with serum procalcitonin. J Renal Inj Prev. 2016;5(3):108-11. https://doi.org/10.15171/jrip.2016.23.

17. Saida K, Kamei K, Hamada R, Yoshikawa T, Kano Y, Nagata H, et al. A simple refined approach for renovascular hypertension in children: a ten-year experience. Pediatr Int. 2020;62(8):937-43. https://doi.org/10.1111/ped. 14224.

18. Lajiness MJ, Hintz LJ. Diagnosis and management of urinary tract infections, asymptomatic bacteriuria and pyelonephritis. Nurse Pract Urol. 2020. https://doi.org/10.1007/978-3-030-45267-4 11.

19. Ataee N, Safaeyan B. Renal parenchymal changes in children with acute pyelonephritis using DMSA scan and the relationship with certain biologic factors. Tehran Univ Med J. 2009;67(2):125-31.

20. Tullus K, Shaikh N. Urinary tract infections in children. Lancet. 2020;395(10237):1659-68. https://doi.org/10.1016/S0140-6736(20) 30676-0.

21. Doern CD, Richardson SE. Diagnosis of urinary tract infections in children. J Clin Microbiol. 2016;54(9):2233-42. https://doi.org/10.1128/JCM. 00189-16.

22. Valavi E, Ziaee KajbafT, Ahmadzadeh A, Nikfar R, Najafi R. Clinical correlation between findings of renal scintigraphy and clinical/laboratory findings in children with febrile UTI. Jundishapur Sci Med J. 2012;11(1):35-42.

23. Gari MA. Prevalence of iron deficiency anemia among female elementary school children in Northern Jeddah, Saudi Arabia. J King Abdulaziz Univ Med Sci. 2008;15(1):63-75. https://doi.org/10.4197/med.15-1.6.

24. Budd JR, Durham AP, Gwise TE, Iriarte B, Kallner A, Linnet K, et al. Measurement procedure comparison and bias estimation using patient samples; approved guideline. Clinical Laboratory Standards Institute; 2013.

25. Schwartz GJ, Munoz A, Schneider M, Mak R, Kaskel F, Warady B, et al. New equations to estimate GFR in children with CKD. J Am Soc Nephrol. 2009;20:629-37. https://doi.org/10.1681/ASN.2008030287.

26. Hsu PC, Chen SJ. Obesity and risk of urinary tract infection in young children presenting with fever. Medicine. 2018;97(49): e13006. https://doi. org/10.1097/MD.0000000000013006.

27. Yang $\mathrm{TH}$, Yim HE, Yoo KH. Obesity and a febrile urinary tract infection: dual burden for young children? Urology. 2014;84:445-9. https://doi.org/10. 1016/j.urology.2014.03.032.

28. Mahyar A, Ayazi P, Gholmohammadi P, Moshiri SA, Oveisi S, Esmaeily S. The role of overweight and obesity in urinary tract infection in children. Le Infez Med. 2016;24:38-42.

29. Grier WR, Kratimenos P, Singh S, Guaghan JP, Koutroulis I. Obesity as a risk factor for urinary tract infection in children. Clin Pediatr. 2016;55(10):9526. https://doi.org/10.1177/0009922815617974.

30. Jaksic E, Bogdanovic R, Artiko V, Saranovic DS, Petrasinovic Z, Petrovic M, et al. Diagnostic role of initial renal cortical scintigraphy in children with the first episode of acute pyelonephritis. Ann Nucl Med. 2011;25(1):3743. https://doi.org/10.1007/s12149-010-0431-5.

31. Marcos A, Varela P, Toro O, Nova E, López-Vidriero I, Morandé G. Evaluation of nutritional status by immunologic assessment in bulimia nervosa: 
influence of body mass index and vomiting episodes. Am J Clin Nutr. 1997;66:491S-S497. https://doi.org/10.1093/ajcn/66.2.491S.

32. Marcos A, Varela P, Toro O, López-Vidriero I, Nova E, Madruga D, et al. Interactions between nutrition and immunity in anorexia nervosa: a 1-y follow-up study. Am J Clin Nutr. 1997;66:485S-S490. https://doi.org/10. 1093/ajcn/66.2.485S.

33. Kim $Y B$, Tang $C L$, Koo JW. Is vaginal reflux associated with urinary tract infection in female children under the age of 36 months? Kor J Pediatr. 2018:61(1):17-23. https://doi.org/10.3345/kjp.2018.61.1.17.

34. McCormick DP, Sarpong K, Jordan L, Ray LA, Jain S. Infant obesity: are we ready to make this diagnosis? J Pediatr. 2010;157(1):15-9. https://doi.org/ 10.1016/j.jpeds.2010.01.028.

35. Twells L, Newhook LA. Can exclusive breastfeeding reduce the likelihood of childhood obesity in some regions of Canada? Can J Public Health. 2010;101:36-9. https://doi.org/10.1007/BF03405559.

36. Ataei N, Milanii Housaini SM, Compani F. Early Tc99m dimercaptosuccinic acid (DMSA) scan in children with acute pyelonephritis. Tehran Univ Med J. 2003;61(2):119-26.

37. Amaral CM, Casarini DE, Andrade MC, Cruz ML, Macedo A. Study of serum and urinary markers of the renin angiotensin-aldosterone system in myelomeningocele patients with renal injury detected by DMSA. Int Braz J Urol. 2020;46(5):805-13. https://doi.org/10.1590/s1677-5538.ibju.2019. 0797.

38. Toker A, ZiypakT, Orsal E, Laloglu E, Bedir F, Aksoy Y. Is urinary kidney injury molecule-1 a noninvasive marker for renal scarring in children with vesicoureteral reflux? Urology. 2013;81(1):168-72. https://doi.org/10. 1016/j.urology.2012.09.004.

39. Breinbjerg A, Jørgensen CS, Frøkiær J, Tullus K, Kamperis K, Rittig S. Risk factors for kidney scarring and vesicoureteral reflux in 421 children after their first acute pyelonephritis, and appraisal of international guidelines. Pediatr Nephrol. 2021. https://doi.org/10.1007/s00467-021-05042-7.

40. Megged O. Bacteremic vs nonbacteremic urinary tract infection in children. Am J Emerg Med. 2017;35(1):36-8. https://doi.org/10.1016/j.ajem. 2016.09.060.
41. Vysakh A, Raji NR, Suma D, Jayesh K, Jyothis M, Latha MS. Role of antioxidant defence, renal toxicity markers and inflammatory cascade in disease progression of acute pyelonephritis in experimental rat model. Microb Pathog. 2017;109:189-94. https://doi.org/10.1016/j.micpath.2017.05.047.

42. Fahimi D, Khedmat L, Afshin A, Noparast Z, Jafaripor M, Beigi EH, Ghodsi M, Izadi A, Mojtahedi SY. Clinical manifestations, laboratory markers, and renal ultrasonographic examinations in 1-month to 12-year-old Iranian children with pyelonephritis: a six-year cross-sectional retrospective study. BMC Infect Dis. 2021;21:189. https://doi.org/10.1186/ s12879-021-05887-1.

43. Abdel-Zaher AO, Farghaly HS, El-Refaiy AE, Abd-Eldayem AM. Effect of hypercholesterolemia on hypertension-induced renal injury in rats: Insights in the possible mechanisms. J Cardiovasc Med Cardiol. 2020;7:39-46. https://doi.org/10.17352/2455-2976.000110.

44. Jung SJ, Lee JH. Prediction of cortical defect using C-reactive protein and urine sodium to potassium ratio in infants with febrile urinary tract infection. Yonsei Med J. 2016;57(1):103-10. https://doi.org/10.3349/ymj.2016. 57.1.103.

45. Viana MB. Anemia and infection: a complex relationship. Rev Bras Hematol Hemoter. 2011;33:90-2. https://doi.org/10.5581/1516-8484.20110024.

46. Sadeghi Z, Kajbafzadeh AM, Tajik P, Monajemzadeh M, Payabvash S, Elmi A. Vitamin $E$ administration at the onset of fever prevents renal scarring in acute pyelonephritis. Pediatr Nephrol. 2008;23(9):1503-10. https://doi. org/10.1007/s00467-008-0853-7.

47. Parajuli NP, Maharjan P, Parajuli H, Joshi G, Paudel D, Sayami S, et al. High rates of multidrug resistance among uropathogenic Escherichia coli in children and analyses of ESBL producers from Nepal. Antimicrob Resist Infect Control. 2017;6(1):9. https://doi.org/10.1186/s13756-016-0168-6.

\section{Publisher's Note}

Springer Nature remains neutral with regard to jurisdictional claims in published maps and institutional affiliations.
Ready to submit your research? Choose BMC and benefit from:

- fast, convenient online submission

- thorough peer review by experienced researchers in your field

- rapid publication on acceptance

- support for research data, including large and complex data types

- gold Open Access which fosters wider collaboration and increased citations

- maximum visibility for your research: over 100M website views per year

At BMC, research is always in progress.

Learn more biomedcentral.com/submissions 